\title{
The Effect of Human Resources Practices on Organizational Commitment: A Jordanian Study
}

\author{
Taghrid S. Suifan (Ph.D) \\ Department of Business Management, Faculty of Business, The University of Jordan \\ E-mail: t.suifan@ju.edu.jo
}

Received: June 4, 2015 Accepted: July 9, 2015 Published: July 26, 2015

doi:10.5296/jmr.v7i4.7972

URL: http://dx.doi.org/10.5296/jmr.v7i4.7972

\begin{abstract}
The effect of human resources practices on organizational commitment was examined in this study using a sample of 500 subjects randomly selected from employees working for public and private organization in various industries in Amman, the capital city of Jordan. Of the mailed questionnaires, 431 questionnaires were returned with a response rate of 86 percent. A bulk of scales was adopted from related works to measure constructs. Organizational commitment was measured by organizational commitment scale developed by Meyer and Allen (1997), training was measured using a scale developed by Yahya and Goh (2002), person-organization fit was measured by a scale developed by Netemeyer et al. (1997), and, finally, rewards construct was measured by a scale adopted from Sejjaaka and Kaawaase (2014). The results pointed out that all HR practices examined (training, person-organization fit, and rewards) were significantly and positively associated with organizational commitment. Research limitations and future research directions were brought out.
\end{abstract}

Keywords: Training, Person-organization fit, Rewards, Organizational commitment, Public and private organizations, Amman. 


\section{Introduction}

By virtue of human capital as a main source for productivity and competitive advantage (Khan, 2015), organizations must consider the critical role of human resource practices and make every effort to develop and sustain this capital. The development of human capital can be achieved by HR practices. Literature looks at these practices as antecedents of various organizational outcomes. Findings from Guerci et al. (2015) demonstrated that HR practices enhance the organizational climate. According to Shahnawaz and Juyal (2006), HR practices (i.e. training, employee participation, training and career development) are significantly predicting organizational commitment. Furthermore, HR practices are significant for improving employees' performance and enhancing the achievement of organizational goals (Ahmed \& Akhtar, 2012).

Meyer and Allen (1997) divided HR practices into two types: control-related practices that aim at increasing efficiency and depend on output-based rewards and commitment-related practices that aim at increasing effectiveness and depend on conditions facilitate the achievement of the organizational goals. Employee empowerment, intensive communications about employees' tasks and performance, training and development, recruitment, and performance-based rewards are examples of commitment-related practices cited by Pfeffer (1998).

This study aims at examining the effect of human resources practices (i.e. training, person-organization fit, and rewards) on organizational commitment in Jordanian public and private organizations in various sectors. Training is a process utilized to increase employees' knowledge and skills to be able to perform specific tasks. Lamba \& Choudhary (2013) argued that the purpose of training is to fill the gap between job requirements and employee competencies, and to improve employees' behavior and performance. For Chew et al. (2005), motivation-based HR practices such as rewards are more related to organizational commitment than ability-based practices like training. With reference to person-organization fit, Chew et al. (2005) further highlighted the influence of this practice on organizational commitment. According to them, person-organization fit predicts employee turnover intention and organizational commitment.

Various studies have been done on the relationship between HR practices and organizational commitment. However, the current study is a large scale Jordanian study conducted in several industries. The paper is constructed as follows. The next section reviews related works and shows hypotheses formulation. Section three displays the methodology of research including participants, measures, the conceptual model of the study, and instrument validity and reliability tests. Section four clarifies data analysis and interpretations of results. Section five contains discussion of the study results. Finally, limitations and future research directions were stated.

\section{Related works and hypotheses formulation}

\subsection{Human Resources Practices}

Marescaux et al. (2012) argued that soft HR practices include five practices, which are: training, career planning and development, mentoring, employee involvement and participation, as well as developmental assessment. Farzaneh et al. (2014) identified two types of HR practices, which are 
person-job fit and person-organization fit. López et al. (2006) studied four HR practices: selective hiring, training, compensation and reward, and employee participation. Guerci et al. (2015) divided HR practices into three types: HR practices improve employees' abilities such as selection and training, and practices enhance employee' motivation like performance management, compensation and incentives, and practices enhance opportunities like employee involvement and job design. Joarder et al. (2011) identified six practices including supervisors' support, training and development, job security, job autonomy, compensations, and work conditions. For the present study, three HR practices (training, person-organization fit and rewards) were chosen based on Guerci et al. (2015). Additionally, the selected practices for this study were regarded by Platonova et al. (2013) as innovative practices.

\subsection{Organization Commitment}

The definition of organizational commitment (OC) is related to three concepts comprise identification with the organizational goals, costs coupled with remaining at or leaving the organization, as well as individuals' feelings engagement to continue their job with the organization (Dhar, 2015; Farzaneh et al., 2014; Permarupan et al., 2013; Marescaux et al., 2012). Each concept is related to one component of organizational commitment. Weng et al. (2010) regarded the emotional relationship that connects an employee to his or her organization as affective commitment, which in turn encourage him or her to continue with the organization. The costs of leaving the organization that considered by individuals represent the second component of organizational commitment (i.e. continuous commitment). Finally, individuals' feelings engagement exemplifies the main feature of normative commitment.

\subsection{HR Practices and organizational Commitment}

Marescaux et al. (2012) divided the outcomes of HR practices into three types: attitudes towards the job itself, like job satisfaction, attitudes towards the organization such as organizational commitment, and behavior intentions like turnover intention. Commensurate with Bambacas (2010), HR practices are one of the most major predictors frequently utilized to investigate the level of organizational commitment.

\subsubsection{Training}

Dhar (2015) investigated the role of organizational commitment in the relationship between training opportunities provided for employees at Indian hotels and service quality. His findings support the hypothesis that training affects service quality through organizational commitment. In their research study, Şendoğdu et al. (2013) accepted the hypothesis that there is a positive association between training, either in multiple functions or on job skills, and organizational commitment. Naqvi and Bashir (2015) studied the relationship between some aspects of HR practices and found a significant and positive correlation between training and organizational commitment. Ling et al. (2014) also found a positive relationship between training and organizational commitment. Based on these studies and the significance of training in inducing organizational commitment, the following hypothesis was drawn:

Ho1: training is positively related to organizational commitment. 


\subsubsection{Person-organization fit}

According to Farzaneh et al. (2014), both person-job fit (PJF) and person-organization fit (POF) bring about various positive organizational outcomes like more satisfied and more committed individuals. In their study on 800 participants, they found that person-job fit as well as person-organization fit were significantly and positively related to organizational commitment. Chew and Chan (2008) examined the impact of key HR practices (i.e. person-organization fit, remuneration and recognition, opportunities to work on challenging assignments, opportunities for training and career development) on organizational commitment. Their findings support the hypothesis that organizational commitment is significantly correlated to person-organization fit. Using a sample of 120 participants working for three companies in Taiwan, the results of Silverthorne's (2004) study revealed that person-organization fit is a key element in predicting employees' organizational commitment level. Consequently, the following hypothesis was formulated:

Ho2: person-organization fit is positively related to organizational commitment.

\subsubsection{Rewards}

Newman and Sheikh (2012) mentioned that rewards include all tangible benefits like pay and promotions, and intangible benefits such as opportunities for participation in decision-making, in addition to social rewards represented by good relationships with colleagues or supervisors. Sejjaaka and Kaawaase (2014) pointed out that rewards can predict organizational commitment. Additionally, Chew and Chan (2008) confirmed the positive relationship between rewards and organizational commitment. According to Naqvi and Bashir (2015), there is a significant and positive correlation between compensation and organizational commitment. As a result, the following hypothesis was proposed:

Ho3: compensation is positively related to organizational commitment.

\section{Methodology}

\subsection{Participants}

Email surveys were used to collect data from participants. The target population of the study comprised of employees working for public and private organization in various industries in Amman. A random sample consisted of 500 individuals was selected. Out of the distributed questionnaires, 431 were returned. The response rate was about 86 percent.

\subsection{Measures}

Organizational commitment was measured in this study by organizational commitment scale developed by Meyer and Allen (1997). The scale has been used by many researchers (Weng et al., 2010) to measure OC dimensions (i.e. affective, continuous and normative commitment). Training was measured using a scale developed by Yahya and Goh (2002). Person-organization fit (PJF) was measured by a scale developed by Netemeyer et al. (1997). Both Farzaneh et al. (2014) Chew and Chan (2008) use this scale to measure person-organization fit. All answers of scales were scored using five-point Likert scale, where 1 represents completely agree and 5 


\section{Macrothink}

Journal of Management Research

ISSN 1941-899X

2015, Vol. 7, No. 4

represents completely disagree. The rewards construct was measured by a scale adopted from Sejjaaka and Kaawaase (2014).

\subsection{Conceptual Model}

HR practices (i.e. training, person-organization fit, and rewards) are the independent variables (IVs) used in this study to predict the overall variance in the dependent variable (DV), i.e. organizational commitment. Five relationships between IVs and DV were hypothesized. The graphical illustration of the study conceptual model is shown in Figure 1.

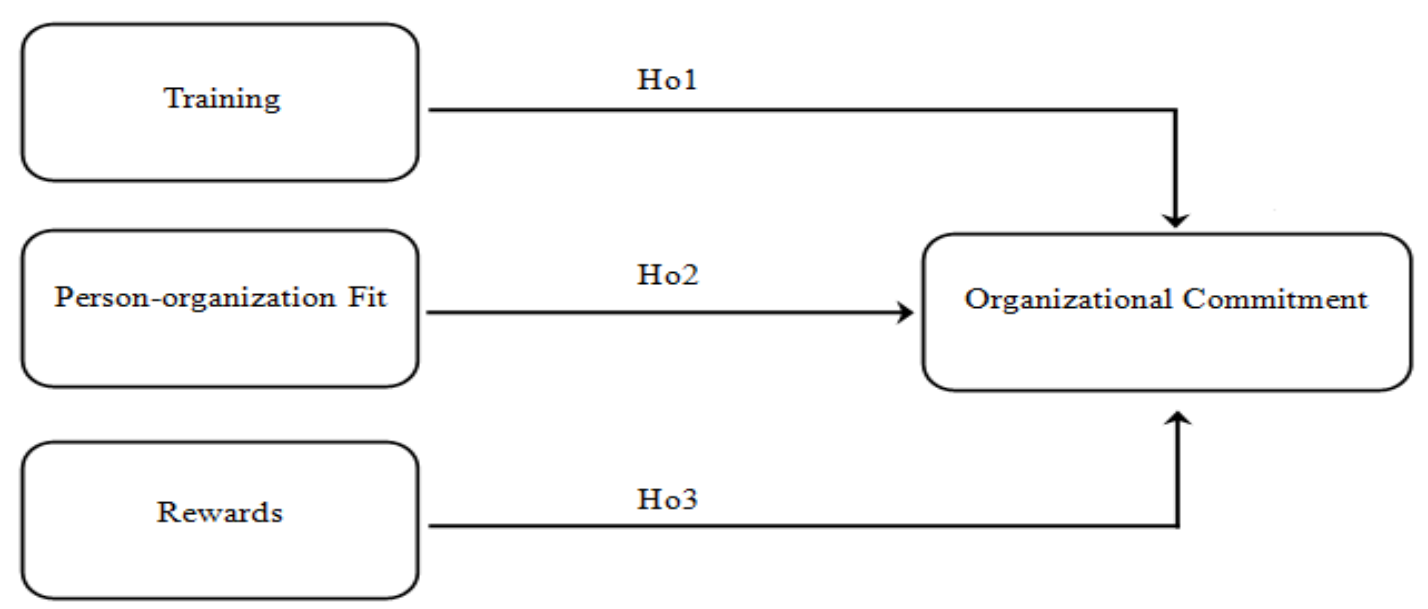

Figure 1. The conceptual model of the study

\section{Data analysis and interpretation}

\subsection{Participants’ Profile}

Table 1 shows frequencies and percentages of participants' demographics. The majority of the participants were males (63 percent). The highest age percentage ( 24 percent) was for $41-45$ years, followed by $46-50$ years (21 percent). Out of participants, 24 percent were from ministries, 21 percent from universities, 20 percent form plans, 18 percent from banking sector, and 17 percent from hospitals. Most participants hold a bachelor degree (59 percent). About 34 percent of participants have 4 to 6 training courses, and 33 percent have 1 to 3 courses. Finally, the percentage of participants with 2 to 5 years experience was 43 percent. 
Table 1. Participants' demographic characteristics

\begin{tabular}{|c|c|c|c|c|c|c|}
\hline & Sex & Age & Industry & Education & Training & Experience \\
\hline Male & $271(63 \%)$ & & & & & \\
\hline Female & $160(37 \%)$ & & & & & \\
\hline $25-30$ & & $41(10 \%)$ & & & & \\
\hline $31-35$ & & $79(18 \%)$ & & & & \\
\hline $36-40$ & & $66(15 \%)$ & & & & \\
\hline $41-45$ & & $105(24 \%)$ & & & & \\
\hline $46-50$ & & $89(21 \%)$ & & & & \\
\hline 51 or above & & $51(12 \%)$ & & & & \\
\hline Banking & & & $78(18 \%)$ & & & \\
\hline Universities & & & $90(21 \%)$ & & & \\
\hline Hospitals & & & $73(17 \%)$ & & & \\
\hline Ministries & & & $104(24 \%)$ & & & \\
\hline Plants & & & $86(20 \%)$ & & & \\
\hline High school & & & & $94(22 \%)$ & & \\
\hline Bachelor & & & & $253(59 \%)$ & & \\
\hline Postgraduate & & & & $84(19 \%)$ & & \\
\hline $1-3$ & & & & & $143(33 \%)$ & \\
\hline $4-6$ & & & & & $145(34 \%)$ & \\
\hline $7-10$ & & & & & $84(19 \%)$ & \\
\hline 11 or above & & & & & $59(14 \%)$ & \\
\hline 1 year or less & & & & & & $61(14 \%)$ \\
\hline $2-5$ years & & & & & & $185(43 \%)$ \\
\hline $6-10$ years & & & & & & $112(26 \%)$ \\
\hline 11 or above & & & & & & $73(17 \%)$ \\
\hline Total & 431 & 431 & 431 & 431 & 431 & 431 \\
\hline
\end{tabular}

\subsection{Test for linearity}

Comparison between means was used in order to test the study variables for linearity. Table 2 displays non-significant levels of relationships between HR practices and the organizational commitment. There is a linear relationship between training, person-organization fit, and rewards and organizational commitment $(\mathrm{F}=0.861, \mathrm{p}>0.05 ; \mathrm{F}=0.236, \mathrm{p}>0.05 ; \mathrm{F}=1.19$, $\mathrm{p}>0.05$ respectively). 
Table 2. Results of test for linearity

\begin{tabular}{lcc}
\hline \multicolumn{1}{c}{ Variables } & $\mathrm{F}$ & Sig. \\
\hline Training * Organizational commitment & 0.861 & 0.328 \\
Person-organization fit * Organizational commitment & 0.236 & 0.416 \\
Rewards * Organizational commitment & 1.19 & 0.527 \\
\hline${ }^{*} \mathrm{p}<0.05$ & & \\
\hline
\end{tabular}

\subsection{Normal distribution test}

One-Sample Kolmogorov-Smirnov $(Z)$ was used to assess the normal distribution of study variables. As shown in Table 3 , all variables of the study were normally distributed $(Z=$ $0.416, p>0.05 ; Z=0.712, p>0.05 ; Z=0.396, p>0.05 ; Z=0.681, p>0.05)$.

Table 3. Results of normal distribution test

\begin{tabular}{lcc}
\hline Variables & $Z$ & Sig. \\
\hline Training & 0.416 & 0.592 \\
Person-organization fit & 0.712 & 0.216 \\
Rewards & 0.396 & 0.327 \\
Organizational commitment & 0.681 & 0.632 \\
\hline${ }^{*} \mathrm{p}<0.05$ & & \\
\hline
\end{tabular}

\subsection{Multicollinearity}

Variance Inflation Factor (VIF) along with tolerance values were extracted using collinearity diagnostics among independent variables. As evident from Table 4, the regression model used in this study is free from multicollinearity, since all VIFs were less than 5, and all tolerances were greater than 0.05 . VIF (Tolerance) for training $=2.061(0.948)$, VIF (Tolerance) for person-organization fit $=1.124$, VIF $($ Tolerance $)$ for rewards $=1.317$.

Table 4. Results of multicollinearity tests

\begin{tabular}{lcc}
\hline \multicolumn{1}{c}{ Variable } & VIF & Tolerance \\
\hline Training & 2.061 & 0.948 \\
Person-organization fit & 1.124 & 0.961 \\
Rewards & 1.317 & 0.927 \\
\hline DV: organizational commitment & & \\
\hline
\end{tabular}

\subsection{Correlation of Variables}

Table 5 shows the means, standard deviations, and correlations for the study variables. The results showed in Table 2 indicated a significant as well as positive correlation among all variables. There is a significant positive association between training and organizational commitment $(\mathrm{r}=$ $0.873, \mathrm{p}<0.05$ ). Equally, there is a significant positive association between person-organization fit and organizational commitment $(\mathrm{r}=0.711, \mathrm{p}<0.05)$. Furthermore, there is a significant positive association between rewards and organizational commitment $(r=0.914, p<0.01)$. 
Table 5. Means, standard deviations and correlations

\begin{tabular}{lrcccccc}
\hline \multicolumn{1}{c}{ Variables } & $\mathrm{N}$ & $\mathrm{M}$ & $\mathrm{SD}$ & 1 & 2 & 3 & 4 \\
\hline 1. training & 431 & 4.213 & 0.841 & - & & & \\
2. person-organization fit & 431 & 3.988 & 0.722 & $0.612 * *$ & - & \\
3. rewards & 431 & 4.014 & 0.697 & $0.531 *$ & $0.671 *$ & - & \\
4. OC & 431 & 3.874 & 0.753 & $0.873 *$ & $0.711^{*}$ & $0.914 * *$ & - \\
\hline$* \mathrm{p}<0.05, * * \mathrm{p}<0.01$ & & & & & & & \\
\hline
\end{tabular}

\subsection{Model fit and hypotheses testing}

A simultaneous regression analysis was conducted to examine the effect of dependent variables (HR practices, i.e. training, person-organization fit, and rewards) on the dependent variable (i.e. the organizational commitment). Results of regression analysis are shown in Table 6. Pearson correlation coefficient $(\mathrm{r})$ value equals 0.847 which indicates a strong correlation between study variables. $R^{2}$ equals 0.72 which means that all $H R$ practices predict about 72 percent of the variance in the organizational commitment. $F(3,427)$ with a $p$ value less than 0.05 asserted that all HR practices significantly predict organizational commitment. Moreover, the standardized beta coefficients with p-values less than 0.05 suggest that rewards as an antecedent of organizational commitment is the most affective variable in the relationship between HR practices and organizational commitment $(\mathrm{B}=0.384, \mathrm{p}<0.05)$, followed by training $(\mathrm{B}=0.359, \mathrm{p}<0.05)$, then person-organization fit $(B=0.271, \mathrm{p}<0.05)$.

Table 6. Regression analysis results

\begin{tabular}{clccccccc}
\hline Model & & $\mathrm{r}$ & $\mathrm{R}^{2}$ & $\mathrm{~F}$ & $\mathrm{P}$ & $\mathrm{t}$ & $\mathrm{B}$ & $\mathrm{P}$ \\
\hline 1 & & 0.847 & 0.72 & 11.69 & 0.000 & & & \\
& Constant & & & & & 14.413 & & 0.000 \\
& Training & & & & & 3.171 & 0.359 & 0.000 \\
& P-O fit & & & & & 4.512 & 0.271 & 0.000 \\
& Rewards & & & & & 4.872 & 0.384 & 0.000 \\
\hline$* \mathrm{p}<0.05$ & & & & & & & &
\end{tabular}

\section{Discussion and Conclusion}

The present study examined the effect of HR practices on organizational commitment. For the first hypothesis, it was found that training programs provided to employees positively affect their level of organizational commitment. The second hypothesis examined in this study, which hypothesizes a positive effect of -organization fit on organizational commitment, was supported. The effect of rewards on organizational commitment presumed by the third hypothesis was also verified. Such results are consistent with previous research. Gavino et al. (2011) investigated the relationships between HR practices and attitudinal outcomes and found a positive relationship between training and organizational commitment. In his study on sixteen large companies in the UAE, Behery (2009) concluded a positive relationship between person-organization fit and organizational commitment. Rewards-related results were supported by Asghar et al. (2011). Such findings have practical implications. HR practices differ in their ultimate goals. Training programs, for example, are designed to build competencies through acquisition of skills and knowledge, while rewards are directed to enhance employees' motivation. On the other hand, 
practices such as employees' involvement and job design are planned to improve employees' opportunities Guerci et al. (2015). In that case, managers should pay more attention for diversity of HR practices when implemented to ensure equilibrium outcomes of such practices.

\section{Limitations and future research}

Three HR practices (training, person-organization fit, and rewards) were tested in this study; further studies are needed to investigate the impact of other HR practices such as recruitment and selection on organizational commitment, working environment, person-job fit, job enrichment, job security, communication, performance appraisal, opportunities for advancement, and information sharing. Moreover, this study was conducted in Amman; future research could investigate the same constructs throughout Jordan.

\section{References}

Ahmed, S., \& Akhtar, M. (2012). Development of scale to assess effective execution of human resources practices for general public sector universities. International Journal of Applied Science and Technology, 2(7), 211-223.

Asghar, R., Zaheer, A., \& Mughal, A. \& Khalid, S. (2011). Implementation of HR practices in University Teachers of Pakistan. Information Management and Business Review, 3(3), 148-157.

Bambacas, M. (2010). Organizational handling of careers influences managers' organizational commitment. Journal of Management Development, 29(9), 807-827. http://dx.doi.org/10.1108/02621711011072513

Behery, M. (2009). Person/organization job-fitting and affective commitment to the organization Perspectives from the UAE. An International Journal, 16(2), 179-196. http://dx.doi.org/10.1108/13527600910953928

Chew J., Girardi, A., \& Entrekin, L. (2005). Retaining core staff: the impact of human resource practices on organizational commitment. Journal of Comparative International Management, $8(2), 23-42$.

Chew, J., \& Chan, C. (2008). Human resource practices, organizational commitment and intention to stay. International Journal of Manpower, 29(6), 503-522. http://dx.doi.org/10.1108/01437720810904194

Dhar, R. (2015). Service quality and the training of employees: The mediating role of organizational commitment. Tourism Management, 46, 419-430. http://dx.doi.org/10.1016/j.tourman.2014.08.001.

Farzaneh, J., Farashah, A., \& Kazemi, M. (2014). The impact of person-job fit and person-organization fit on OCB: The mediating and moderating effects of organizational commitment and psychological empowerment. Personnel Review, 43(5), 672-691. http://dx.doi.org/ 10.1108/PR-07-2013-0118

Gavino, M., Martinez, P., \& Malos, S. (2011). Contingent employment relationships between tour guides and tour operators in Ecuador: Human resource management practices and attitudinal 
outcomes. Employ Respons Rights Journal, 22, 213-234. http://dx.doi.org/10.1007/s10672-009-9138-y.

Guerci, M., Radaelli, G., Siletti, E., Cirella, S., \& Shani, R. (2015). The Impact of Human Resource Management Practices and Corporate Sustainability on Organizational Ethical Climates: An Employee Perspective. Journal of Business, 126, 325-342. http://dx.doi.org/10.1007/s10551-013-1946-1.

Joarder, M., Sharif, M. \& Ahmed, K. (2011). Mediating role of affective commitment in HRM practices and turnover intention relationship: A study in a developing context. Business and Economics Research Journal, 2(4), 135-158.

Khan, M. (2015). Development of human capital through institution of Islamic waqf. International Journal of Information, Business and Management, 7(3), 36-50.

Lamba, S., \& Choudhary, N. (2013). Impact of HRM practices on organizational commitment of employees. International Journal of Advancements in Research \& Technology, 2(4), 407-423.

Ling, L. Qing, T., \& Shen, P. (2014). Can training promote employee organizational commitment? The effect of employability and expectation value. Nankai Business Review International, 5(2), 162-186. http://dx.doi.org/10.1108/NBRI-09-2013-0034.

López, S., Peón, J., \& Ordás, C. (2006). Human resource management as a determining factor in organizational learning. Management Learning, 37(2), 215-239. http://dx.doi.org/10.1177/1350507606063443 .

Marescaux, E., Winne, S., \& Sels, L. (2012). HR practices and HRM outcomes: the role of basic need satisfaction. Personnel Review, 42(1), 4-27. http://dx.doi.org/10.1108/00483481311285200.

Meyer, J., \& Allen, N. (1997). Commitment in the workplace: Theory, research and application. Thousand Oaks, CA: Sage Publications.

Naqvi, S., \& Bashir, S. (2015). IT-expert retention through organizational commitment: A study of public sector information technology professionals in Pakistan. Applied Computing and Informatics, 11, 60-75. http://dx.doi.org/10.1016/j.aci.2011.11.001.

Netemeyer, R., Boles, J., McKee, D., \& McMurrian, R. (1997). An investigation into the antecedents of organizational citizenship behaviors in a personal selling context. The Journal of Marketing, 61(3), 85-98. http://dx.doi.org/10.2307/1251791.

Newman, A., \& Sheikh, A. (2012). Organizational rewards and employee commitment: A Chinese study. Journal of Managerial Psychology, 27(1), 71-89. http://dx.doi.org/10.1108/02683941211193866.

Permarupan, P., Saufi, R., \& Kasim, R. \& Balakrishnan, B. (2013). The Impact of organizational climate on employee's work passion and organizational commitment. Social and Behavioral Sciences, 107, 88-95. http://dx.doi.org/10.1016/j.sbspro.2013.12.403

Pfeffer, J. (1998). The human equation: building profits by putting people first, Boston, MA: Harvard Business School Press. 


\section{Macrothink}

Journal of Management Research

ISSN 1941-899X 2015, Vol. 7, No. 4

Platonova, E., Hernandez, S., \& Moorehouse, R. (2013). Innovative human resource practices in U.S. hospitals: An empirical study. Journal of Healthcare Management, 58(4), 290-303.

Sejjaaka, S., \& Kaawaase, T. (2014). Professionalism, rewards, job satisfaction and organizational commitment amongst accounting professionals in Uganda. Journal of Accounting in Emerging Economies, 4(2), 134-157. http://dx.doi.org/ 10.1108/JAEE-01-2012-0003.

Şendoğdu, A., Kocabacak, A., \& Güven, Ş. (2013). The relationship between human resource management practices and organizational commitment: A field study. Social and Behavioral Sciences, 99, 818-827. http://dx.doi.org/10.1016/j.sbspro.2013.10.553

Shahnawaz, M., \& Juyal, R. (2006). Human resource management practices and organizational commitment in different organizations. Journal of the Indian Academy of Applied Psychology, 32(3), 171-178.

Silverthorne, C. (2004). The impact of organizational culture and person-organization fit on organizational commitment and job satisfaction in Taiwan. The Leadership \& Organization Development Journal, 25(7), 592-599. http://dx.doi.org/10.1108/01437730410561477.

Weng, Q., McElroy, J., Morrow, P., \& Liu, R. (2010). The relationship between career growth and organizational commitment. Journal of Vocational Behavior, 77, 391-400. http://dx.doi.org/10.1016/j.jvb.2010.05.003 .

Yahya, S., \& Goh, W. (2002). Managing human resources toward achieving knowledge management. Journal of Knowledge Management, 6(5), 457-468. http://dx.doi.org/10.1108/13673270210450414. 